\title{
Distribution and forecast of air temperature in determining of heat output of the district heating substation with heat storage
}

\author{
Michat Turski ${ }^{1, *}$, and Robert Sekret $^{1}$ \\ ${ }^{1}$ Faculty of Infrastructure and Environment, Czestochowa University of Technology, \\ ul. Brzeznicka 60A, 42-200 Czestochowa, Poland
}

\begin{abstract}
The aim of this article was to determine the energetic effect of adapting the control method of district heating substation to a solution using dispersed heat storage. The current control method of district heating substation uses the equations for regulating the temperature distribution of the installation water based on the value of the external temperature. This control method causes a significant amount of heat not consumed by end users. To adapt the control method to a solution using dispersed heat storage the following values were analyzed: the forecast of external temperature and duration of episodes with the lowest external temperatures on the heat output of the district heating substation based on 63 heating seasons. Obtained results were presented for a district heating substation in Poland. The analysis shows that a temperature of $-15^{\circ} \mathrm{C}$ can be adopted as the reference to determine the expected heat output of the district heating substation. On this basis the demand for heat output for central heating purposes was $406 \mathrm{~kW}$ instead of $430 \mathrm{~kW}$. The energetic effect of use dispersed heat storage to compensate the reduced heat output of the district heating substation was $24 \mathrm{~kW}$ with a compensation time of $24.2 \mathrm{~h}$.
\end{abstract}

\section{Introduction}

Searching for the possibility of reduction of low emissions makes district heating systems an interesting solution [1]. However, due to maintaining profitability, existing district heating systems are not suitable for supplying large areas with relatively small heat demand. Therefore, the development of district heating systems is heading towards the idea of an energy-efficient district heating or cooling system [2-4]. An energy-efficient district heating or cooling system is a system in which at least $50 \%$ of energy comes from renewable energy sources or $50 \%$ of energy comes from waste heat or $75 \%$ of heat comes from cogeneration or $50 \%$ of energy and heat comes from the three previous categories [5]. Achieving the energy-efficient district heating system standard for existing and new district heating systems creates problems related to the need to receive additional heat to the district heating network characterized by different parameters and high variability of available heat

\footnotetext{
*Corresponding author: m.turski@is.pcz.pl
} 
over time [6]. Therefore, there is a need to create new solutions adapted to the technologies of energy-efficient district heating systems [7].

Typical engineering solutions used today to improve district heating systems within district heating networks are: lowering of the network water temperature, application of pre-insulated ducts technology, replacement of group district heating substation, to individual ones, regulation of district heating substations and their automation. However, these typical solutions are already insufficient today, because they are limited only to reducing thermal losses on transmission $[8,9]$.

One of the most important problems that limits the development of district heating systems is the considerable difference between the designed and the actual heat demand of buildings connected to the district heating network. The first actions that can reduce this problem may be: increasing the efficiency of the heating installation $[10,11]$, better adaptation of the heating system to the network users' profile, taking into account the frequency and duration of the episodes with the lowest external temperature [12] and taking into account the possibility of so-called passive heat storage methods using the existing infrastructure of the district heating system [13-15].

Currently used methods of design heat output of district heating substations are based on the design temperature of the outside air. But there are observed very rare occurrences of values equal to or lower than the design values for external air temperature during the heating season [16]. As a result, the heat output of substations is oversized and the profitability of the systems decreases [17]. In works [18,19] have been analyzed daily heat load variations in district heating systems and in substations on the basis of external air temperature. It was estimated that avoiding these variations would improve 3-6\% of annual heat supply in district heating systems. In addition, the thermal demand of buildings is reduced due to the intensive thermal modernization of existing buildings and the introduction of new building technologies with extremely low heating energy requirements $[20,21]$. Heat output calculations of district heating substations do not take into account distribution and forecast of air temperature or active methods of heat storage [22, 23]. It is therefore considered that the current solution is not accurate enough.

Therefore, for improving the energy efficiency of a district heating system, it is increasingly common to use the regulation of network parameters based on the predicted thermal demand of buildings connected to the heating network. In work [24] heat loads for individual consumers in district heating systems were predicted with coefficient of determination $\mathrm{R}^{2}$ in range of $0.05-0.9$, but it was only in short term about 15-60 min. E.g. the ANN (artificial neural networks) model is able to predict the engine performance and exhaust emissions with coefficient of determination $\mathrm{R}^{2}$ in range of $0.97-0.99$ [25]. In case of district heating system an adaptive neuro-fuzzy inferences system (ANFIS) is able to predict the heat loads for individual consumers with coefficient of determination $\mathrm{R}^{2}$ in range of $0.01-0.96$ [26]. Simulation results indicate that further improvements on model are needed especially for prediction horizons greater than $1 \mathrm{~h}$. In work [27] models were developed using the novel method based on Extreme Learning Machine (ELM) for time horizon 1-24 h. Estimation and prediction results of ELM models were better than genetic programming (GP) and artificial neural networks (ANNs) models and achieved coefficient of determination $\mathrm{R}^{2}$ in range of $0.8-0.96$. But the measurement data was in a similar range which could have a beneficial effect on coefficient od determination $\mathrm{R}^{2}$. Therefore, it is possible to use external air temperature values from measurements made in previous heating seasons to predict heat output oa a district heating substation [28, 29].

After increasing the efficiency of the heating installation, taking into account the profiles of district heating network users dependent on the external temperature and the use of passive heat storage methods, uncollected heat may still occur, therefore, there is a further need to regulate the district heating network. The possibility of district heating 
network further regulation is provided by active heat storage systems. Many publications describe active heat storage in the district heating network. For example, work [30] describes the solution of a multi-scale model of storage tanks. Results show that primary energy consumption can be reduced up to $12 \%$, while total costs can be reduced up to about $5 \%$. Other publications and reviews [31-34] describe distributed heat storages, and hourly, daily, weekly, and seasonal heat and cold storages. But many described solutions in these works are simulations only. The latest solutions for heat storage in a district heating network in a dispersed system were studies on the use of PCM heat acumulators [35-38]. However, in these studies, the reduction of the heat output was not considered.

Therefore, it should be carried out research into the use of alternative methods of determining the heat output of district heating substations with usage of distribution and forecast of air temperature and active methods of heat accumulation.

\section{Methodology}

The study object was a single function district heating substation with heat output equal $Q_{\mathrm{p}\left(-20^{\circ} \mathrm{C}\right)}=430 \mathrm{~kW}$ to central heating purposes. Operation parameters of the analyzed district heating substation were shown on Figure 1. The substation was quality-controlled (temperature control), via weather regulation. The regulation of substation operation parameters corresponded to the outside air temperatures in the range of $t_{\mathrm{e}} \epsilon<-20^{\circ} \mathrm{C} ;+12^{\circ} \mathrm{C}>$. The temperature regulation of the supply water $t_{1 \mathrm{i}}$ was carried out in accordance with the thermal flow equations $1-3$. Return water temperature $t_{2 \mathrm{i}}$ is the result of instability of heat reception $Q_{i}$. The mass flow was constant and was equal $\dot{m}=5.13 \mathrm{~kg} / \mathrm{s}$. The heating system was located in the area of standard climatic conditions for Poland and therefore, according to Polish regulations, the calculation value of external temperature was $t_{\mathrm{e}, \mathrm{p}}=-20^{\circ} \mathrm{C}$. Design temperature of supply water (at outside air temperature $t_{\mathrm{e}, \mathrm{p}}=-20^{\circ} \mathrm{C}$ ) was $t_{1, \mathrm{p}\left(-20^{\circ} \mathrm{C}\right)}=80^{\circ} \mathrm{C}$, and design temperature of return water was $t_{2, \mathrm{p}\left(-20^{\circ} \mathrm{C}\right)}=60^{\circ} \mathrm{C}$.

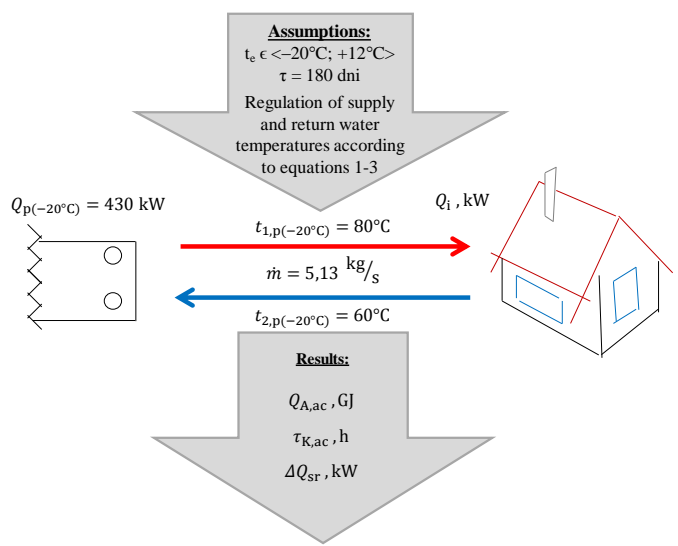

Fig. 1. Operation parameters of the analyzed district heating substation.

where:

$$
\begin{gathered}
t_{1, \mathrm{p}}=t_{\mathrm{i}, \mathrm{p}}+0.5 \cdot\left(t_{1, \mathrm{p}\left(-20^{\circ} \mathrm{C}\right)}-t_{2, \mathrm{p}\left(-20^{\circ} \mathrm{C}\right)}\right) \cdot \varphi+\left[0.5 \cdot\left(t_{1, \mathrm{p}\left(-20^{\circ} \mathrm{C}\right)}+t_{2, \mathrm{p}\left(-20^{\circ} \mathrm{C}\right)}\right)-t_{\mathrm{i}, \mathrm{p}}\right] \cdot \varphi^{1 /(1+m)},{ }^{\circ} \mathrm{C} \\
t_{2, \mathrm{p}}=t_{1, \mathrm{p}}\left(t_{1, \mathrm{p}\left(-20^{\circ} \mathrm{C}\right)}-t_{2, \mathrm{p}\left(-20^{\circ} \mathrm{C}\right)}\right) \cdot \varphi,{ }^{\circ} \mathrm{C} \\
\varphi=t_{\mathrm{i}, \mathrm{p}}-t_{\mathrm{e}} /\left(t_{\mathrm{i}, \mathrm{p}}-t_{\mathrm{e}, \mathrm{p}}\right),-
\end{gathered}
$$

$t_{1, \mathrm{p}}$ or $t_{2, \mathrm{p}}-$ temperature of supply water or return water, ${ }^{\circ} \mathrm{C}$, 
$t_{\mathrm{i}, \mathrm{p}}-$ calculation value of internal temperature, ${ }^{\circ} \mathrm{C}$,

$t_{1, \mathrm{p}\left(-20^{\circ} \mathrm{C}\right)}$ or $t_{2, \mathrm{p}\left(-20^{\circ} \mathrm{C}\right)}-$ designed temperature of supply water or return water, ${ }^{\circ} \mathrm{C}$,

$t_{\mathrm{e}}-$ external temperature, ${ }^{\circ} \mathrm{C}$,

$t_{\mathrm{e}, \mathrm{p}}-$ calculation value of external temperature, ${ }^{\circ} \mathrm{C}$,

$\varphi-$ load factor, - ,

$m$ - characteristic exponent, - .

An assumption of the analysis is to demonstrate the nominal potential of determining the equivalent heat output of the district heating substation with use of distribution and forecast of air temperature and active heat storage.

The amount of heat that is possible to accumulate in the district heating substation, $Q_{\mathrm{A} \text {,ac }}$, was calculated from equation (4) as a product of capacity $V$, density $\rho$, specific heat $c_{\mathrm{p}}$, and temperature difference $\Delta T$ between loaded and unloaded heat accumulator $\Delta T=t_{1}-t_{0}$.

$$
Q_{\mathrm{A}, \mathrm{ac}}=V \cdot \rho \cdot c_{\mathrm{p}} \cdot \Delta T \cdot 10^{-6}, \mathrm{GJ}
$$

where:

$Q_{\mathrm{A}, \mathrm{ac}}$ - amount of heat that is possible to accumulate in the district heating substation, GJ,

$V$ - volume of heat accumulator, $\mathrm{m}^{3}$,

$\rho$ - density of water, $\mathrm{kg} / \mathrm{m}^{3}$,

$c_{\mathrm{p}}$ - specific heat of water, $\mathrm{kJ} /(\mathrm{kg} \mathrm{K})$,

$\Delta T$ - temperature difference, $\mathrm{K}$.

Compensation time of the heat output reduction of district heating substation with usage of additional heat accumulator was calculated from equation (5):

$$
\tau_{\mathrm{K}, \mathrm{ac}}=Q_{\mathrm{A}, \mathrm{ac}} /\left(0.0036 \cdot \Delta Q_{\mathrm{sr}}\right), \mathrm{h}
$$

where:

$\tau_{\mathrm{K}, \mathrm{ac}}$ - compensation time of the heat output reduction of district heating substation, $\mathrm{h}$, $Q_{\mathrm{A}, \mathrm{ac}}-$ amount of heat that is possible to accumulate in the district heating substation, GJ, $\Delta Q_{\mathrm{sr}}$ - assumed heat output reduction of district heating substation with usage of additional heat accumulator, $\mathrm{kW}$.

\section{Analysis}

Based on the assumed real time series of average daily external air temperatures from the years 1953 to 2016, presented on Figure 2, it is shown that time series are characterized by cyclical fluctuations resulting from weather conditions and seasonal fluctuations, which are significant due to the duration of the heating season.

In order to take account of cyclical fluctuations, it is necessary to reduce the averaged time series of the model. After analyzing the best fit of the model depending on the length of time series, the most favorable values of the coefficient of determination $\mathrm{R}^{2}$, which is a measure of fit quality, are reached for 15 years. The $\mathrm{R}^{2}$ values are shown in Figure 3.

Based on the obtained $\mathrm{R}^{2}$ value, the forecast of the external average daily air temperature for 2017-2021 is presented from a 15-year time series. The distribution and forecast of external average daily air temperature for 2017-2021 are shown in Figure 4. Values of interest for the analysis area are the minimum expected values for the average daily external air temperature. Seasonal fluctuations in the time series of the forecast 
indicate that the minimum average external air temperature in the period 2017-2021 is equal to $-11.7^{\circ} \mathrm{C}$ for a 15 -year time series.

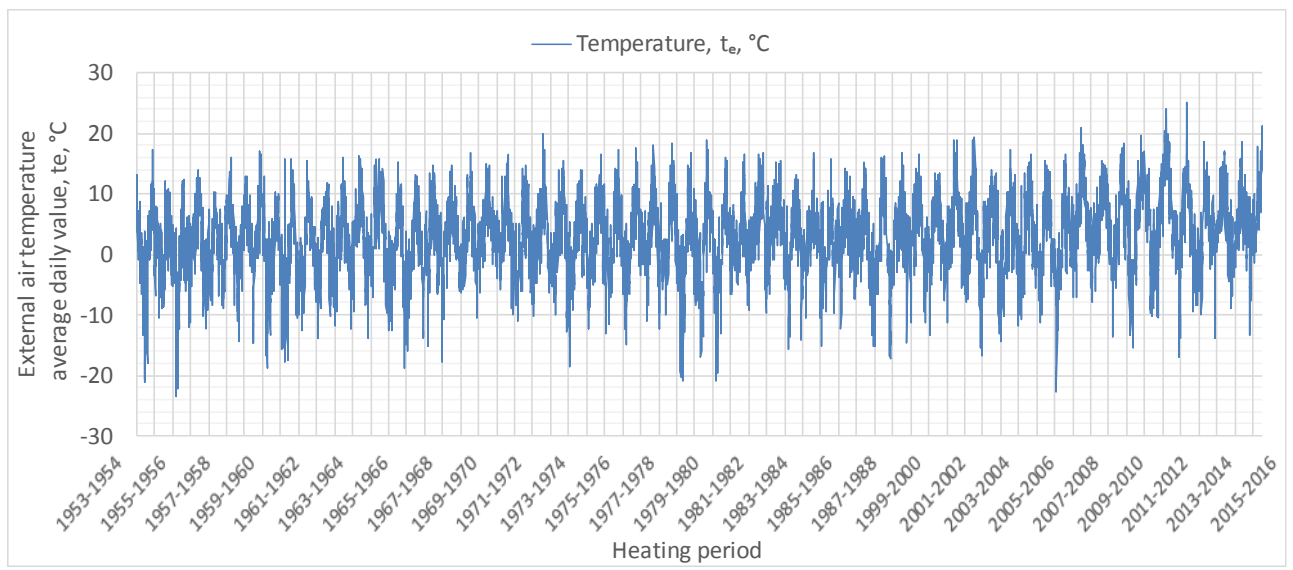

Fig. 2. Average daily external air temperatures.

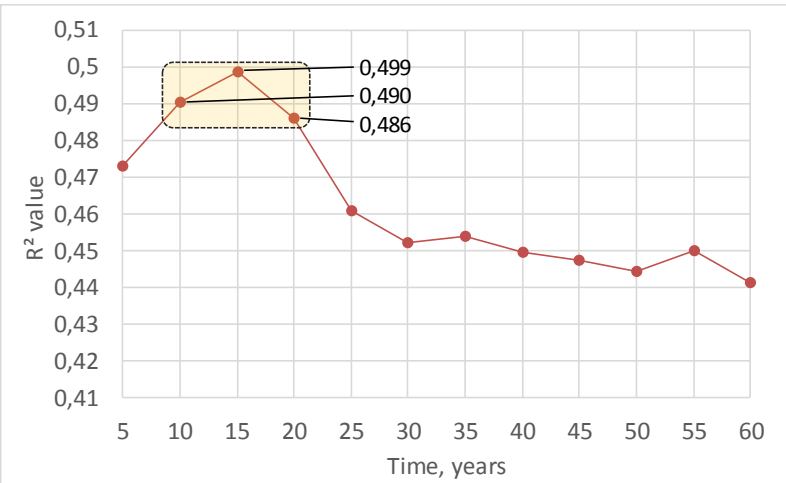

Fig. 3. Values of the coefficient of determination $\mathrm{R}^{2}$ as a measure of fit quality depending on the duration of heating season.

Considering the correlation values of the coefficient of determination $\mathrm{R}^{2}$, these results are not very accurate. However, on the basis of an analysis of the frequency and duration of episodes with the lowest values of external air temperature, presented on Figure 5, could be concluded that one-day episodes of average daily external air temperature occur 71 times for temperatures below $-15^{\circ} \mathrm{C}$ and five-day episodes occur only 10 times below that temperature for 63 heating seasons. On this basis, it can be statistically assumed that the average daily external air temperatures below $-15^{\circ} \mathrm{C}$ occur once a season. Considering the occurrence of multi-day episodes, they occur extremely rarely, especially three, four and five-day episodes.

On this basis, it can be assumed that possibility of reduction the heat output of the district heating substation can be considered to the level of building heat demand based on external design temperature of $-15^{\circ} \mathrm{C}$. Of course, this doesn't mean that temperatures lower than the external design temperature will not occur. If the average daily external air temperatures lower than the design external temperature occur, the lack of heat output will be compensated by the heat accumulator. 


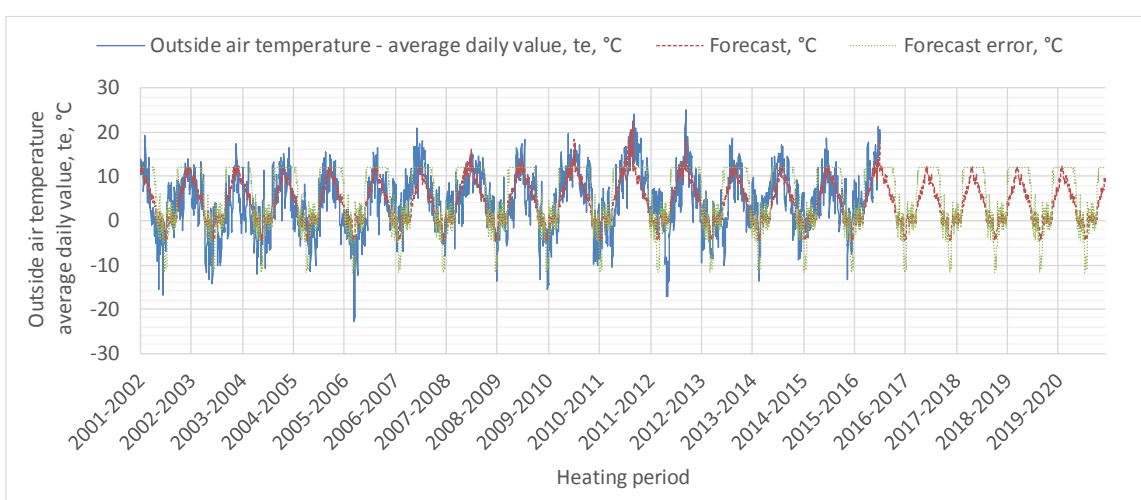

Fig. 4. Distribution and forecast of external average daily air temperature for 2017-2021 based on a 15-year time series.

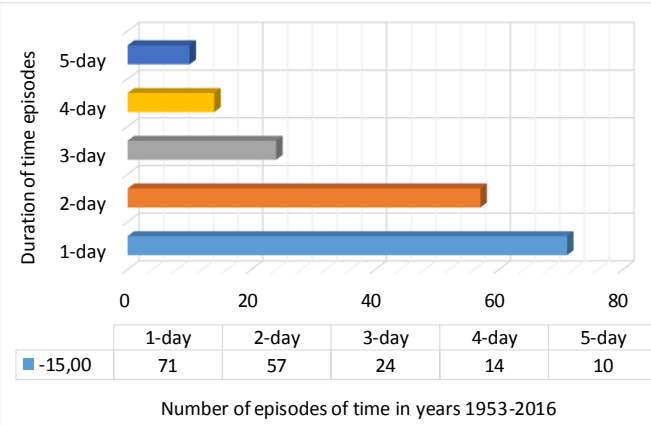

Fig. 5. Frequency and duration of episodes with the lowest values of external air temperature.

The possibility of compensation the district heating substation heat output was determined as the effect resulting from the use of extra heat storage - additional heat accumulator. Figure 6 shows the compensation times as a function of the assumed source heat output reduction, $\Delta Q_{s r}$. According to equations (4) and (5) were calculated respectively the amount of heat that is possible to accumulate in the district heating substation, $Q_{\mathrm{A}, \mathrm{ac}}$ and the compensating time of heat output reduction using the active method of heat storage additional heat accumulator, $\tau_{K, a c}$. It is possible to compensate the reduction of heat output of the district heating substation in the range of $1-50 \mathrm{~kW}$ and even higher by using the thermal storage capacity of an additional heat accumulator over a time period from less than $6 \mathrm{~h}$ to $200 \mathrm{~h}$ and more. However, significant values resulting from reduction of heat output of the district heating substation (more than 5\%) and compensation times (more than 24 hours) occur in the narrower range (Figure 6). It is desirable to achieve the longest compensation time for any given reduction of heat output of the district heating substation. As the analysis showed, it can be statistically assumed that 1-day episodes below $-15^{\circ} \mathrm{C}$ occur once a season. Therefore, it is crucial to choose a heat accumulator that will secure the building for at least 24 hours. A reduction of heat output of the district heating substation of $24 \mathrm{~kW}$ corresponds to a compensation time of $24.2 \mathrm{~h}$, with water volume of heat accumulator of $10 \mathrm{~m}^{3}$. In case of lower volume of heat accumulator these assumptions have not been achieved. 


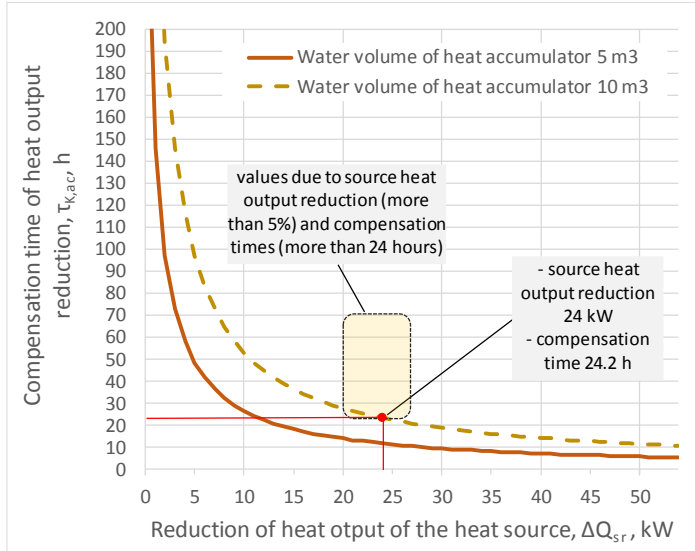

Fig. 6. Compensation times as a function of the assumed reduction of heat output of the district heating substation.

\section{Conclusions}

If they are compared distribution and forecast of air temperature it could be concluded that in this particular case the frequency and duration of episodes with the lowest values of external air temperature seems to be more accurate. One-day episodes of average daily external air temperature occur 71 times for temperatures below $-15^{\circ} \mathrm{C}$ and five-day episodes occur only 10 times below that temperature for 63 heating seasons. In the other hand, the forecast indicate that the minimum average external air temperature is equal to $-11.7^{\circ} \mathrm{C}$. Considering the correlation values of the coefficient of determination $\mathrm{R}^{2}$, forecast results are not very accurate. The potential of use of an additional heat accumulator and its compensation times for reduction of heat output of the district heating substation are sufficient. The analysis of average daily external temperatures shows that a temperature of $-15^{\circ} \mathrm{C}$ can be adopted as the reference to determine the expected heat output of district heating substation. Thus, the demand for heat output for central heating purposes will be $406 \mathrm{~kW}$ instead of $430 \mathrm{~kW}$. In that case, the equivalent heat output required to cover the needs of central heating (provided from heat accumulator) would be $24 \mathrm{~kW}$ with a compensation time of $24.2 \mathrm{~h}$.

The material has been prepared in terms of the Czestochowa University of Technology statutory research BS/PB-401-301/18 'Systems for supplying buildings with heat, cold and electricity'.

\section{References}

1. K. Wojdyga, M. Chorzelski, E. Rozycka-Wronska, J. of Clean. Prod. 75, $157-165$ (2014)

2. H. Lund, S. Werner, R. Wiltshire, S. Svendsen, J. Thorsen, F. Hvelplund, B. Mathiesen, Energy 68, 1-11 (2014)

3. M. Turski, R. Sekret, Rynek Energii 119, 27-34 (2015)

4. M. Turski, R. Sekret, Rynek Energii 122, 66-74 (2016)

5. Energy Efficiency Act of 20 May 2016 as implementation of Directive 2012/27/EU of the European Parliament and of the Council of 25 October 2012

6. M. Turski, R. Sekret, Chem. Process Eng. 37, 293-304 (2016) 
7. M. Turski, E3S Web of Conferences 44, 00181 (2018)

8. K. Wojdyga, Energy and Build. 40, 2009-2014 (2008)

9. M. Turski, R. Sekret, J. of Power Technol. 96, 444-448 (2016)

10. T. Cholewa, A. Siuta-Olcha, C. A. Balaras, Energy and Build. 151, 487-493 (2017)

11. T. Cholewa, I. Balen, A. Siuta-Olcha, Energy and Build. 179, 156-164 (2018)

12. M. Turski, R. Sekret, E3S Web of Conferences 22, 00180 (2017)

13. M. Turski, R. Sekret, Energy and Build. 179, 49-56 (2018)

14. J. Heier, C. Bales, V. Martin, Renew. and Sustainable Energy Rev. 42, 1305-1325 (2015)

15. J. Kensby, A. Trüschel, J. O. Dalenbäck, Appl. Energy 137, 773-781 (2015)

16. M. Santamouris, C. Cartalis, A. Synnefa, D. Kolokotsa, Energy and Build. 98, 119-124 (2015)

17. A. Colmenar-Santos, E. Rosales-Asensio, D. Borge-Diez, F. Mur-Pérez, Energy 85, 403-414 (2015)

18. H. Gadd, S. Werner, Appl. Energy 106, 47-55 (2013)

19. H. Gadd, S. Werner, Appl. Energy 108, 176-183 (2013)

20. P. Späth, H. Rohracher, Energy Policy 78, 273-280 (2015)

21. K. Wojdyga, Renew. Energy 34, 2935-2939 (2009)

22. K. Wojdyga, Int. J. of Energy and Power Eng. 5, 237-244 (2014)

23. K. Klajic, D. Gvozdenac, S. Vukmirović, Energy 45:304-311 (2012)

24. M. Protić, S. Shamshirband, M. H. Anisi, D. Petković, D. Mitić, M. Raos, M. Arif, K. A. Alam, Energy 82, 697-704 (2015)

25. J. Cay, I. Korkmazb, A. Çiçekc, F. Karad, Energy 50, 1-10 (2013)

26. S. Shamshirband, D. Petković, R. Enayatifar, A. H. Abdullah, D. Marković, M. Lee, R. Ahmad, Renew. and Sustainable Energy Rev. 48, 760-767 (2015)

27. S. Sajjadi, S. Shamshirband, M. Alizamir, P. L. Yee, Z. Mansor, A. A. Manaf, T. A. Altameem, A. Mostafaeipour, Energy and Build. 122, 222-227 (2016)

28. M. Protić, S. Shamshirband, D. Petković, A. Abbasi, M. L. M. Kiah, J. A. Unar, L. Živković, M. Raos, Energy 87, 343-351 (2015)

29. V. D. Stevanovic, B. Zivkovic, S. Prica, B. Maslovaric, V. Karamarkovic, V. Trkulja, Energy Convers. and Manag. 50, 2167-2173 (2009)

30. V. Verda, F. Colella, Energy 36, 4278-4286 (2011)

31. H. Gadd, S. Werner, Advances in Thermal Energy Storage Systems 18, 467-478 (2015)

32. A. Lake, B. Rezaie, S. Beyerlein, Renew. Sustain. Energy Rev. 67, 417-425 (2017)

33. M. Sayegh, J. Danielewicz, T. Nannou, M. Miniewicz, P. Jadwiszczak, K. Piekarska, H. Jouhara. Renew. Sustain. Energy Rev. 68, 1183-1192 (2017)

34. R. Marx, D. Bauer, H. Drueck, Energy Procedia 57, 2706-2715 (2014)

35. K. Nogaj, M. Turski, R. Sekret, MATEC Web of Conferences 174, 01002 (2018)

36. K. Nogaj, M. Turski, R. Sekret, E3S Web of Conferences 22, 00124 (2017)

37. K. Nogaj, M. Turski, R. Sekret, COW 49, 91-95 (2017)

38. K. Nogaj, M. Turski, R. Sekret, COW 48, 47-52 (2017) 